\title{
Tackling HIV: Genetic vs. Immune CCR5 targeting
}

Assunta Venuti and Lucia Lopalco*

Division of Immunology, Transplantation and Infectious Diseases, San Raffaele Scientific Institute, Via Stamira d'Ancona, 20-20131 Milan, Italy

\begin{abstract}
Recent advances in gene targeting have proposed new approaches to treat HIV infection, focused on CCR5, which is a key molecule in virus entry as well as in infection maintenance. Ex vivo cell targeting could make T-cells resistant to infection while reducing cell reservoirs where HIV can escape total eradication. Immunization could provide prompt receptor down regulation and preventive immunity also in limited resources settings. Innovative, gene-based methods and immune-based interventions aimed at silencing CCR5 expression in vivo will be compared.
\end{abstract}

Keywords: HIV; CCR5; Gene Therapy; Vaccine; Humoral Immunity

\section{Introduction}

In the Nineties, observations about the role of RANTES and other chemokines in HIV infection were reported [1]; almost at the same time, CCR5-Delta32, a rare mutation in the corresponding chemokine receptor, was found to confer resistance [2-6]. Both findings pointed out the key role of CCR5, the major HIV coreceptor, in establishment and in maintenance of HIV infection.

Since that evidence, CCR5 has become an important potential preventive and therapeutic target for blocking HIV-1 entry in vivo; its interest was reinforced by the common observation that homozygous Delta32 carriers show normal inflammatory and immune reactions. CCR5 was associated with inflammation in several conditions, such as age-related degenerative diseases, rheumatoid arthritis and cancer; the absence of CCR5 expression was not definitely associated with any medical dysfunction, hence not excluding the feasibility of anti-CCR5 interventions $[7,8]$. Consequently, a growing number of strategies aimed at preventing CCR5 function in HIV entry and spread have been designed and tested.

Anti-CCR5 strategies include small molecule drugs, such as maraviroc, ex vivo gene targeting introducing Delta32-like mutations in $\mathrm{CD} 4+\mathrm{T}$ lymphocytes and/or in hematopoietic stem cells, administration of chemokine analogues able to block the coreceptor inside cells and prevent its surface signalling, the generation of antibodies aimed at downregulating CCR5 receptors from target cells.

All of these antiviral strategies showed their efficacy and safety in preclinical assays; maraviroc is in clinical therapy since 2007; gene targeting has been already tested in some patients undergoing Hematopoietic Stem Cells (HSC) transplantation; intra- and extracellular immunization have been successfully tested in animal models.

This review will not consider development of drug inhibitors and chemokine analogues; it will focus genetic and immune-based techniques aimed at reducing or preventing CCR5 expression on target cells, i.e. CCR5 gene targeting and anti-CCR5 immunization strategies.

\section{Gene Targeting}

Since 1996, clinical observations showed that individuals carrying an homozygous mutations impairing CCR5 expression were highly resistant to HIV infection $[2,3,6]$. As summarized in Table 1, the status of heterozygous Delta32 carrier does not confer full protection from HIV infection but has been associated with slower progression; in fact, heterozygous Delta32 mutation was frequently observed in Long
Term Non Progressor subjects (LTNP) [9-11]. Delta32 mutation, which causes the premature truncation of CCR5 molecule and prevents its surface expression, was not found to cause any immune dysfunction in homozygous subjects; however, it has been associated with increased susceptibility to West Nile virus or to tick-borne encephalitis $[12,13]$.

Conversely, CXCR4 molecule, the second HIV coreceptor, is involved in hematopoiesis and neurogenesis, therefore its function is not dispensable and its mutations similar to Delta 32 cannot be observed in vivo [14].Other genetic polymorphisms have been associated with HIV protection, as those involving SDF-1alpha (a CXCR4 ligand), RANTES (a CCR5 ligand) or CCR2 (a chemokine receptor sharing high homology to CCR5) $[15,16]$.

However, human CD4+T lymphocytes where CCR5 and CXCR4 were inactivated by intrakine expression, did show normal proliferation and response to antigens, mitogens, cytokines and other chemokines [17]. These findings seem confirmed by a recent study, showed that conditional CXCR4 knock out in T cells was not lethal in mice, allowing the study of CXCR4 involvement in arthritis [18].

Transplantation with CCR5 Delta32/Delta32 hematopoietic cells was first performed in an HIV-infected patient with acute myeloid leukemia; once recovered, the patient remained free from viremia for 20 months without receiving antiretroviral therapy (ART) [19]. Subsequently, CCR5- CD4+ donor cells were found in submucosal gastrointestinal (GI) and in glial brain biopsies some months after transplantation, showing that these cells have slowly colonized host tissues, and suggesting that their expansion could have reduced viral reservoirs [20]. Immune analysis of circulating lymphocytes showed that host memory CD4+ T lymphocytes have been replaced by resistant donor cells, therefore subtracting an important pool of virus targets. Most importantly, CCR5 ablation has not induced virus switch either in CXCR4 dependent (so called X4 viruses) or in dual tropic (so called $\mathrm{R} 5-\mathrm{X} 4$ viruses). As a confirm, the patient interrupted ART without

*Corresponding author: Lucia Lopalco, Division of Immunology, Transplantation and Infectious Diseases, San Raffaele Scientific Institute, Via Stamira d'Ancona, 20-20131 Milan, Italy, Tel: 390-226-437-936; Fax: 390-226-435-381; E-mail: lopalco.lucia@hsr.it

Received July 04, 2014; Accepted August 28, 2014; Published September 07 2014

Citation: Venuti A, Lopalco L (2014) Tackling HIV: Genetic vs. Immune CCR5 targeting. J AIDS Clin Res 5: 344. doi:10.4172/2155-6113.1000344

Copyright: ( 2014 Venuti A, et al. This is an open-access article distributed unde the terms of the Creative Commons Attribution License, which permits unrestricted use, distribution, and reproduction in any medium, provided the original author and source are credited. 


\begin{tabular}{|c|c|c|c|c|}
\hline Anti-CCR5 gene targeting & Ref & Evidence & Benefits & Limits \\
\hline $\begin{array}{l}\text { Natural Delta32 } \\
\text { homozygosis }\end{array}$ & [2-6] & $\begin{array}{l}\text { Spontaneous mutation occurring } \\
\text { in } 4-18 \% \text { of European and } \\
\text { Askenazi Jews people. } \\
\text { Not found in Asian and Pacific } \\
\text { indigens. }\end{array}$ & $\begin{array}{l}\text { Lack of CCR5 surface } \\
\text { expression. } \\
\text { No signs of immune alterations. } \\
\text { Resistance to R5 HIV infection. }\end{array}$ & $\begin{array}{l}\text { No resistance to X4 or dual R5/X4 } \\
\text { strains. } \\
\text { High sensitivity to West Nile virus } \\
\text { and tick-borne encephalitis. }\end{array}$ \\
\hline $\begin{array}{l}\text { Transplantation of CCR5-/- } \\
\text { cells (HST or T } \\
\text { lymphocytes) }\end{array}$ & {$[19,20,29]$} & $\begin{array}{l}\text { Clinical infusion of modified } \\
\text { cells in patients undergoing } \\
\text { cytoreductive treatment. }\end{array}$ & $\begin{array}{l}\text { Resistance to HIV infection. } \\
\text { Long-term cell survival } \\
\text { GI mucosal colonization. } \\
\text { Brain colonization } \\
\text { Reduction of HIV reservoirs? } \\
\text { Heritable DNA modification. } \\
\text { Definitive cell cure. }\end{array}$ & $\begin{array}{l}\text { Off-target genotoxicity (e.g. CCR2). } \\
\text { Oncogenesis. } \\
\text { CXCR4 is required for HSC } \\
\text { maturation in bone marrow. } \\
\text { Multiple treatment cycles? } \\
\text { Selection of resistant strains. } \\
\text { Mucosal efficacy? }\end{array}$ \\
\hline $\begin{array}{l}\text { CCR5 and/or CXCR4 KO } \\
\text { by Zn-finger Nucleases in } \\
T \text { cells }\end{array}$ & [29] & $\begin{array}{l}\text { Ex vivo transient expression of } \\
\text { viral vectors carrying ZFNs }\end{array}$ & $\begin{array}{l}\text { Resistance to HIV infection. } \\
\text { Mucosal protection? } \\
\text { Reduction of HIV reservoirs? } \\
\text { Definitive cell cure? }\end{array}$ & \multirow{3}{*}{$\begin{array}{l}\text { Off-target toxicity } \\
\text { Insertional mutagenesis? } \\
\text { Lentivirus-induced activation or } \\
\text { mobilization of endogenous LTR? } \\
\text { Unknown long-term safety issues. }\end{array}$} \\
\hline $\begin{array}{l}\text { CCR5 KO } \\
\text { by TALENs or CRISPRs in T cells }\end{array}$ & & $\begin{array}{l}\text { Preclinical study in mice } \\
\text { receiving ex vivo modified T } \\
\text { cells }\end{array}$ & $\begin{array}{l}\text { Lower off-target activity than } \\
\text { ZFNs. }\end{array}$ & \\
\hline $\begin{array}{l}\text { Double CCR5+CXCR4 } \\
\text { KO } \\
\text { by ZFNs in T cells }\end{array}$ & & Ex vivo trial & $\begin{array}{l}\text { Total resistance to HIV } \\
\text { infection. }\end{array}$ & \\
\hline Ribozymes & & $\begin{array}{l}\text { In vitro } \\
\text { Ex vivo trial }\end{array}$ & Preventing CCR5 expression. & $\begin{array}{l}\text { Lentivirus-induced activation or } \\
\text { mobilization of endogenous LTR? }\end{array}$ \\
\hline $\begin{array}{l}\text { Intrabodies-mediated } \\
\text { CCR5 intracellular } \\
\text { retention }\end{array}$ & & Ex vivo assay & $\begin{array}{l}\text { Preventing CCR5 expression. } \\
\text { Resistance to R5-HIV infection. }\end{array}$ & $\begin{array}{l}\text { Excess of intracellular protein } \\
\text { entrapment }\end{array}$ \\
\hline
\end{tabular}

Table 1: Anti-CCR5 gene/expression targeting.

incurring viral rebound and antiviral antibodies vanished over time, suggesting that HIV was no longer expressed [20]. After six years of HIV remission, the "Berlin patient" is considered the first (and unique) case of successful HIV cure since now, even if minimal HIV expression could be still present, at levels beyond limits of detection achieved by present technology [21]. Other HIV-positive patients underwent HSC transplantation to treat leukemia or lymphoma, but HIV rebound was observed after transplant and ART and immunosuppressive therapy were required to control viral load and Graft-versus-Host (GVH) disease; most of these patients died after transplant [22]. The mechanisms involved in HIV eradication in "Berlin patient" only are not yet fully understood. This patient underwent severe particular transplant conditions different from those ones applied to the other patients who died, suggesting that total body irradiation or the engraftment with Delta32 cells from a CCR5 donor might have been critical differential aspects in the case of the Berlin patient [22].

Transplantation with Delta32 homozygous HSC associated with ART is considered a promising way to restore immune system with cells resistant to HIV infection and to reduce HIV reservoir cells [23]. However, this approach presents several limitations, such as the shortage of Delta32 homozygous donors [24], the requirement of severe cytoreductive treatments before and of immunosuppressive and antiviral therapies after the procedure and the consequent economic burden, all of whom make this practice uniquely applicable to HIV patients with haematologic tumors in Western countries $[22,25]$.

Other strategies focused CCR5 Delta32 homozygosis by means of gene disruption, antisense RNAs, intracellular expression of chemokines or antibodies (Table 1).

Engraftment of T cells is fater, and CD4+ cells proliferate rapidly ex vivo and in vivo; HSC grow slower and require more extensive cytoreductive conditioning to achieve an initial advantage over host T-cells, but can differentiate to all cell lineages. Due to their fast growth once engrafted, HSCs are more prone to degenerate in tumors than
T-cells, due to the possible off-target, mutagenetic or trans-activating effects [26]. On the other hand, CCR5 gene knock out (KO) could have a protective role towards donor cells activation and dissemination, since T-cell migration towards inflammatory loci depends on CCR5 receptors [31]; especially CCR5 density on cell surface was observed to increase T-cell migration in Graft-versus-Host disease (GVHD) [28].

\section{Gene Knock out}

Transient expression of specific endonucleases under the control of adeno- or lentiviral vectors was aimed at introducing CCR5 mutations and at preventing its transcription or translation in CD4+ lymphocytes [22,25]. Different semisynthetic nucleases have been build, which put together a DNA binding domain, such as Zinc Fingers (ZF), and an endonuclease function $(\mathrm{N})$, usually provided by Fok $I$ restriction enzyme (Table 1).

Zinc Finger Nucleases (ZFNs) take advantage of the most versatile and most used DNA binding proteins, have been used in many cell types and also tested in ex vivo human trials [29]. Other DNA binding proteins, such as the Transcription Activator-Like Effectors (TALEs), large proteins of vegetal origin, have already been assayed in vitro, showing a comparable efficiency to ZFNs; no infusion assays, even in humanized mice, have still tested the safety of this approach [30]. Another promising method to be exploited in gene editing is the CRISPR/Cas9 (clustered regularly interspaced palindromic repeats sequences) system, which usually serves to bacteria to inactivate plasmid and phage DNA and to elude host innate immunity by inducing multiple nicks under thecontrol of a guide RNA [25]. CRISPR/Cas9 has been successfully used to target human cells and disrupt CCR5 gene, but off-targeting remains a major limit to be overcome [31,32].

In order to obtain a double strand DNA break and to increase target specificity, a ZF and a nuclease domain work on each DNA strand, and the whole ZFN protein is a dimer. DNA recognition ensured by a ZF domain usually spans 9-18 bp [25]. DNA breaks undergo cell repair 
systems, which are often prone to introduce mutations and deletions and therefore lead to reduced or blocked gene expression in a high proportion of treated cells. Even the induction of a single CCR5Delta32 hit can be helpful in gene editing procedures, since increases the proportion of CCR5-homozygous cell population generated by ZFN expression; in fact, therapeutic success depends on the proportion of cells carrying biallelic CCR5 disruption [29]. On the other hand, the strong DNA affinity or the prolonged expressions of ZFNs within target cells have been associated with off-target effects, i.e. mutagenesis or disruption of undesired or unspecific cellular genes. Due to its homology to CCR5, the CCR2 gene, coding for the chemokine receptor binding the Monocyte Chemo attracting Protein-1 (MCP-1), is one of the most frequent off-targets of ZFN [30,33].

Finally, the complete CCR5 inactivation should prevent virus switch to X4 or dual-tropic viruses in the early phase of HIV infection, but if the CCR5 inactivation happens later during HIV infection, a double CCR5-CXCR4 targeting should be performed. Double CCR5-CXCR4 gene disruption has been performed in human cell lines coinfected with two adenoviral vectors carrying the two specific ZFNs. Coinfection with an R5 and a X4 HIV strains enriched the in vitro population of resistant $\mathrm{T}$ cells from $9 \%$ to $99 \%$, confirming their resistance. Similar results were observed in CD4+ T primary cells, which were infused in humanized mice and challenged with infectious $\mathrm{R} 5$ and $\mathrm{X} 4$ tropic viruses. Up to $10 \%$ of resistant human cells were found in mice spleens; proportion of cells carrying CCR5 and CXCR4 gene inactivation reached $69 \%$ and $73 \%$, respectively; these encouraging results need to be further confirmed before applying to human therapy [34].

\section{Antisense RNA}

To shut down CCR5 expression, several RNA-based strategies have been assayed for more than ten years (Table 1). Different approaches were shown effective to reduce CCR5 expression, working through RNA silencing (siRNA), antisense RNAs targeting different viral and cellular genes or ribozymes with catalytic activity [35-40].

Differently from gene editing strategies, RNA silencing or antisense shut-down require the continuous expression of therapeutic RNA; suitable viral vectors should work ex vivo or possibly in vivo, therefore bypassing requirements of cell culture, autologous cells cytoreduction and reinfusionof treated cells.

Adenoviruses and pseudotyped lentivirus vectors have been successfully used to transduce siRNA-coding sequences within cells; while the former vectors remain as episomes and can be lost after some cell cycles, the latter ones can make genes stably integrated in chromosomes, but with a higher risk of mutagenesis. Conditional replication of lentivirus vectors could hypothetically result beneficial, because could contribute to spread therapeutic genes to cells already carrying HIV proviruses, but the risk of insertional mutagenesis and reactivation of endogenous retroviruses cannot be excluded [41]. Similarly to what observed with gene editing, off-targeting activity and over-expression of antisense RNA may result toxic [38]; in addition, undesired activation of innate immunity, driven by double stranded RNA (dsRNA) via Toll-like receptors, could be observed $[46,43]$.

Silencing RNA (siRNA) is an innate cellular mechanism to regulate gene expression that takes advantage of short antisense RNA (about 20 bp) complementary to a specific mRNA and commits it to degradation. ShRNA are short hairpin RNA, precursor of siRNA, which are processed by Dicer endonuclease to become guide RNA and address the silencing complex (RISC) to the targetmRNA [44]. Partial or complete CCR5 shut-down in $\mathrm{T}$ cells has been achieved with various viral vectors, ranging from SV40 to lentiviruses, under the control of promoters with different strength $[36,38,39,45]$. Rhesus CD34+ cells, i.e. precursor of T-cells, monocytes and macrophage lineages, transduced with a lentivirus vector carrying an H1-promoter controlled shRNA, showed a 3-10-fold reduction in CCR5 surface expression and partial resistance to SIVmac challenge; once infused in macaques, reconstituted $\mathrm{T}$ lymphocytes population without signs of toxicity [37]. Another study assessed the stable expression of a shRNA in macrophages derived from fetal liver CD34+ cells; CCR5 downregulation was over $90 \%$ in differentiate macrophages, conferring viral protection without apparent signs of toxicity [46].

The transduction of an antisense RNA complementary to CCR5 sequence reduced receptor surface expression by $98 \%$ and blocked R5 HIV strain infectivity more than 50\% [47].

Ribozymes are catalytic RNA molecules able to cut target mRNA in one or more fragments (Table1); different CCR5 ribozymes have been designed and successfully tested in human cells [48].Stable expression of a multimeric hammerhead in human $\mathrm{T}$ cells decreased receptor expression and nearly abolished infectivity of a R5 HIV strain, without affecting X4-mediated infection [49]. Another ribozyme, transduced in CD34+ cells by a retroviral vector, did not affect cell differentiation in $\mathrm{T}$ cells lineages and macrophages cultured in a mouse model of thymic differentiation [35]. Anti CCR5 ribozymes were also included in multitarget vectors; similarly to ART combinations, lentiviral vectors carrying different blocking agents should prevent the development of resistance to genetic therapies.

A triple combination of HIV tat and rev decoys and an anti-CCR5 ribozyme was tested in CD34+ cells; expression of therapeutic genes in differentiated monocytes reduced HIV R5 infectivity following an additive mode, the triple combination being the most effective among the combinations assayed [50].

\section{Intracellular Chemokines and Antibodies}

The increased expression of RANTES, MIP-1 $\alpha$ and MIP- $1 \beta$ chemokines, and the consequent internalization of CCR5 receptor, have been considered natural protective factors in HIV infection [4,5]. Therefore, chemokine analogues appeared promising drug candidates to confer mucosal protection from HIV entry, with lower risks of inducing drug resistance [51].

A tricky way to achieve inhibition of CCR5 expression has been accomplished through expression of intracellular CCR5 ligands, such as modified chemokines and antibodies (Table 1).

Genes coding for CCR5 and CXCR4 ligands, i.e. RANTES and SDF$1 a$, were modified to be targeted within endoplasmic reticulum (ER). Both molecules worked as molecular decoys and effectively prevented both receptors from surface exposure; once transduced in human T-cell lines and in Peripheral Blood Mononuclear Cells (PBMCs), singularly or in pair, conferred the expected resistance to R5 and/or X4 HIV strains upon challenges $[13,52,53]$.

Similar results were confirmed by a recent study, where intracellular RANTES genes, controlled by EF1-alpha promoter, were efficiently transduced in human cells by a lentiviral vector after CD3 and CD28 antibody stimulation [54]. Intrakine expression reduced, but not completely removed, CCR5 molecules from cell surface; expression levels of other surface receptors, such as CCR1 and CCR3, which usually bind RANTES, was found reduced by effect of the intrakine. Interestingly, real-time PCR analysis revealed a low copy number of proviral DNA in transduced cell cultures; differently from control cells, 
where viral DNA increased over time, treated lymphocytes maintained a constant amount of viral DNA over three weeks [54].

Moreover, different genetic association between Long Term Non Progressor status and copy number variation of CCL3L1 gene encoding for MIP-1 $\alpha$ have been published in the last few years [55-56] and in particular some isoforms of MIP-1a has shown to be very potent agonists of CCR5 [57-58].

The use of intracellular antibodies rather than chemokines could prevent undesired interactions withredundant CCR receptors (Table 1).ST6, a Fab fragment from a $\mathrm{mAb}$ recognizing a unique sequence in CCR5 N-terminus, was engineered to become a single chain antibody (scFv) endowed with an ER retention peptide. Intracellular expression of $\mathrm{scFv}$ completely blocked surface labelling of CCR5 molecule in cytofluorimetric assays both in human and in rhesus cells, while CXCR4 expression was unaffected. Modified cells became resistant to R5 HIV challenge and to R5-mediated cell-cell fusion, showing the effective removal of surface CCR5 [59]. A subsequent study showed that modified primary $\mathrm{T}$ cells carrying CCR5 intrabody were protected from HIV transmission, once interacting with activated, antigen-presenting, dendritic cells pulsed with R5 HIV. Transduced CD34+ human cells, infused in NOD/SCID (nonobese diabetic/severe combined immunodeficiency) mice, differentiated in CD4+ and CD8+ cell lineages, showing stable intrabody expression and retaining HIV resistance [60]. Finally, anti-CCR5, single chain antibodies were also used to specifically target viral pseudotyped lentiviral vectors to CCR5expressing cells [61].

Similarly to ART, combined gene targeting interventions should be required to achieve complete virus suppression [48]; however, the induction of virus resistance and the survival of long-lasting cell sanctuaries cannot be fully excluded[27,30].

\section{Immunization studies}

All attempts to block CCR5 molecule through host immune responses have to cope with two major factors: the highly flexible, poor immunogenic structure of the antigen and the need to elicit host autoimmunity and to break immune tolerance towards a self antigen.

Moreover, anti-CCR5, as all antibodies, could exert antiviral activity through many different mechanisms, including binding competition, steric hindrance, receptor internalization, block of virus transcytosis across epithelial cell layers, complement fixation or AntibodyDependent T-cell-Mediated Cytotoxicity (ADCC) [62,63]. No present studies have either defined what is the most effective way in which antiCCR5 antibodies exert anti-HIV activity or what is the CCR5 domain to be preferred to induce the most effective antibodies.

CCR5 molecule is a G-protein coupled receptor (GPCR), with a typical structure made of seven transmembrane domains; $\mathrm{N}$-terminus and three extracellular loops (ECL1, 2 and 3), are the immunogenic regions and account for about a fourth of its whole sequence (90 out of 352 aminoacids). The two longer domains, the $\mathrm{N}$-terminus and the second extracellular loop (ECL2), are involved in HIV binding (chemokines only bind ECL2 domain), and host the immunodominant epitopes recognized by the majority of monoclonal antibodies [64-66]. Chemokines binding to CCR5 determines receptor internalization as well as T-cell and macrophage chemotaxis; chemokine analogue drugs suitable to antiviral therapy should not induce pro-inflammatory, adverse effects [55].

Monoclonal antibodies to N-terminus and ECL2 compete with HIV for binding (ECL2, but not N-terminus, antibodies prevent chemokine binding); some of them may induce receptor internalization. Monoclonal antibodies have been evaluated in several studies [67]; in humanized form, some have been also tested in clinical trials of passive immunization [68-71]. Anti-CCR5 recombinant antibodies have also been isolated by phage libraries, an approach aimed at increasing the chances to obtain highly active, specific antibodies to the expected target $[72,73]$. Single chain antibodies to CCR5, selected from a phage library displaying cyclic constrained peptides, were found to block specific receptor, but not CXCR4 [74].

The ECL1 domain does not bind HIV; its engagement by natural anti-CCR5 antibodies induces a long-lasting receptor internalization, mediated by clathrin-coated pits [75].

Natural anti-CCR5 antibodies were found in various groups of individuals belonging to different ethnic groups, such as the Delta32 homozygous carriers, exposed to CCR5 through sexual intercourse with CCR5+ partners; haemophilic patients, repeatedly exposed to alloantigens found in blood transfusions; HIV-exposed but uninfected sexual partners of HIV-positive patients (ESN or EU or MEU); HIVpositive patients and especially LTNP subjects, who control the disease for years in absence of ART [75-84]. Strikingly, natural antibodies to CCR5, either IgG and IgA, have been detected in serum as well as in other biological fluids, such as saliva, milk, semen and cervicovaginal secretions, where they are likely to exert direct antiviral activity by inducing receptor internalization or by inhibiting mucosal transcytosis of virus particles (i.e. their transfer across cell membranes of mucosal epithelia) (Table 2). Differently from natural antibodies to ECL1, monoclonal antibodies (mAbs), such as 2D7 (ECL2), do not block HIV transcytosis $[78,80-84,86]$.

\begin{tabular}{|c|c|c|c|c|c|c|}
\hline $\begin{array}{l}\text { Anti-CCR5 } \\
\text { antibody }\end{array}$ & Ref & Study & $\begin{array}{l}\text { Immunogen/ } \\
\text { Vector }\end{array}$ & $\begin{array}{l}\text { Adjuvant//Route/ } \\
\text { Schedule }\end{array}$ & Biological features & Limits \\
\hline $\begin{array}{l}\text { Natural ECL1 } \\
\text { Abs }\end{array}$ & {$[75,80,83,84,86]$} & $\begin{array}{l}\text { ESN and LTNP } \\
\text { sera. }\end{array}$ & Natural Ags? & $\begin{array}{l}\text { Low dose Ags } \\
\text { presented by } \\
\text { mucosal route? }\end{array}$ & $\begin{array}{l}\text { Inhibition of MIP-1beta chemotaxis. } \\
\text { Binding to native CCR5 on PBMC. } \\
\text { CCR5 internalization. } \\
\text { Block of HIV transcytosis . } \\
\text { Block of R5-HIV isolates from A, B, } \\
\text { C, E clades }\end{array}$ & Natural, uncommon. \\
\hline $\begin{array}{l}\text { Natural } \\
\text { Nt/ECL2 Abs }\end{array}$ & {$[76-78,85]$} & $\begin{array}{l}\text { Healthy donors } \\
\text { Delta32+ ESN } \\
\text { Delta32+ } \\
\text { CCR5- } \\
\text { HIV+ patients }\end{array}$ & Natural Ags? & Allo Ags exposure? & $\begin{array}{l}\text { Competition for chemokine binding. } \\
\text { Binding to native CCR5 on } \\
\text { transfected or PBMC. } \\
\text { Block of R5-HIV laboratory and } \\
\text { primary isolates. }\end{array}$ & $\begin{array}{l}\text { Natural response observed } \\
\text { in healthy HIVexposed or in } \\
\text { chronic HIV pz. } \\
\text { Not all Abs internalize CCR } 5\end{array}$ \\
\hline $\begin{array}{l}\text { Anti-CCR5 } \\
\text { humanized } \\
\text { mAbs }\end{array}$ & [68-71] & $\begin{array}{l}\text { Passive } \\
\text { immunization } \\
\text { clinical trial }\end{array}$ & $\begin{array}{l}\text { PRO140 } \\
\text { HGS001 }\end{array}$ & $\begin{array}{l}\text { IV infusion in } \\
\text { HIV-positive } \\
\text { patients }\end{array}$ & Well-tollerated, no toxicity. & $\begin{array}{l}\text { IM infusion. } \\
\text { Immune responses to } \\
\text { therapeutic Abs. }\end{array}$ \\
\hline
\end{tabular}

Table 2: Anti-CCR5 immune responses in humans (naturally occurring or upon passive immunization). 
The maintenance of a proper antigen presentation made difficult to reproduce natural anti-CCR5 responses upon immunization; due to their flexibility, $\mathrm{N}$-terminus and CCR5 loops require a conformed status to retain proper immunogenicity [87]. Table 3 summarizes significant preclinical immunizations performed in rodents. Not surprisingly, first immunization experiments failed in achieving the expected responses, probably due to the epitope presentation in form of conjugated, flexible peptides. Specific, albeit scarce, antibodies obtained from peptide immunizations were nevertheless able to bind CCR5 molecule and to block in vitro infection of R5 HIV strains $[88,89]$.Further experiments assayed immunogens endowed with a determined three-dimension conformation: immunization with a cyclic peptide from ECL2 (R168-T177) induced specific antisera in macaques; antibodies bound human and macaque CCR5+ cells and inhibited infection of A and C clades primary R5 HIV and SHIV isolates in vitro [90].

As shown in Table 3, other immunizations took advantage of the Flock House capsid protein (FHV), a conformation-constrained vector, to elicit antibodies to ECL1 (Y89-W102). Systemic and mucosal murine immunization elicited IgG and IgA antibodies in serum and in vaginal fluids. Such antibodies recognized and downregulated CCR5 from human and murine cells, inhibited MIP- $1 \beta$ induced chemotaxis and blocked clade B R5 virus infection in vitro. Similarly to ESN individuals, CD4+ PBMCs from serum and vaginal washes of immunized mice showed lower amounts of endogenous CCR5 receptors [87].

Aminoacid substitutions introduced in ECL1 peptides displayed in the same carrier were found to increase antibody affinity compared to the wild-type peptide (ECL1, A95-A96 vs. wild type D95-F96); according with NMR analysis, substitutions increase peptide stabilization, enhancing its propensity to assume an helical conformation, therefore confirming the elevated flexibility of native ECL1 domain [91].

In order to increase immunogenicity, vaccine strategies also addressed the construction of high density peptide arrays displayed on Virus Like Particle (VLPs) (Table 3), inspired by the fact that viral envelopes crowded with protein spikes are highly immunogenic and could induce neutralizing responses more easily [92]. As a confirm, such VLPs, based on MS2 bacteriophage backbone, were found to enhance immunogenicity of gp120-V3 and ECL2 peptides [93]. Other bacteriophage-based VLPs, carrying CCR5 peptides, achieved strong systemic and local responses, once administered through airways in a preclinical test in rats [94].

A key aspect in CCR5-targeting immunization is the ability to induce mucosal responses, because HIV entry takes place in mucosal districts almost in all cases [95]. Mucosal districts offer both humoral and physical barriers to infection, due to antiviral factors, such as RANTES and defensins, to IgG and IgA, and to morphological features of epithelia $[96,97]$. Strikingly, X4 viruses were found to be restricted in transcytosis and in mucosal infection as well [98-100].

Natural HIV-blocking IgA in mucosal secretions, described in ESN, was already supposed to confer natural resistance to HIV $[80,82,101,102]$. Anti-viral IgA were found to prevent infection in animal challenges and in human trials by exerting a number of antibody-mediated activities, in addition to neutralization of CD4+ cell infection. Most surprisingly, mucosal antiviral activities took place even in the absence of detectable systemic neutralizing responses [103-105].

Immunization by mucosal route (intranasal DNA prima followed by peptide booster) elicited specific IgG and IgA in sera and in mucosal secretions (intestinal, vaginal and lung) to gp120-V3 loop, gp41ELDKWAS epitope and CCR5-ECL2 (R168-S185) peptides [101]. In the same study, long-term IgG and IgA blocking antibodies were still observed 12 months after boosting, suggesting that intranasal DNA priming followed by one peptide/L3 adjuvant booster immunization could induce long-lasting immunogenicity to conformational epitopes [101]. As described in Table3, immunization with a conformationconstrained ECL1 peptide by IM or IN route elicited IgG andespecially IgA antibodies in serum and in vaginal fluids; besides other anti-CCR5 effects, such antibodies caused a marked downregulation of the receptor

\begin{tabular}{|c|c|c|c|c|c|c|}
\hline $\begin{array}{l}\text { Anti-CCR5 } \\
\text { antibody }\end{array}$ & Ref & Study & Immunogen/Vector & Adjuvant/Route/ Schedule & Biological features & Limits \\
\hline $\begin{array}{l}\mathrm{Nt} \text { and ECL2 } \\
\text { Abs }\end{array}$ & [101] & Preclinical, mice & $\begin{array}{l}\text { ECL2 (aa 168-182) } \\
\text { peptide emulsified in } \\
\text { mono-oleate/fatty acid } \\
\text { (L3) adjuvant }\end{array}$ & $\begin{array}{l}\text { IN DNA priming } \\
\text { and booster IM } \\
\text { immunization }\end{array}$ & $\begin{array}{l}\text { Serum and mucosal IgG and IgA } \\
\text { (intestinal, vaginal and lung). } \\
\text { Long-lasting IgG and IgA } \\
\text { ( } 12 \text { months from boosting). } \\
\text { IN DNA prime+peptide booster } \\
\text { induced HIVblocking antibodies and B } \\
\text { memory cells. }\end{array}$ & $\begin{array}{l}\text { Human/simian CCR5 } \\
\text { sequences. } \\
\text { Not conformed peptide. }\end{array}$ \\
\hline ECL1 Abs & {$[87]$} & Preclinical, mice & $\begin{array}{l}\text { ECL1 conformed in } \\
\text { FHV capsid protein }\end{array}$ & $\begin{array}{l}\text { Freund's adjuvant } \\
\text { by IM and IN } \\
\text { administration }\end{array}$ & $\begin{array}{l}\text { IgG and IgA. } \\
\text { Long lasting CCR5 downregulation on } \\
\text { PBMC and mucosal fluids. } \\
\text { Transcytosis inhibition. }\end{array}$ & Human ECL1 sequence. \\
\hline Nt Abs & [89] & $\begin{array}{l}\text { Preclinical, } \\
\text { rabbits }\end{array}$ & $\begin{array}{l}\mathrm{Nt}(\mathrm{M} 1-\mathrm{S} 7) \\
\text { conjugated with } \mathrm{KHL} .\end{array}$ & $\begin{array}{l}\text { Fusion with a Tspecific } \\
\text { peptide } \\
\text { from Tetanus } \\
\text { toxoid }\end{array}$ & $\begin{array}{l}\text { Binding to N-term and } \\
\text { full CCR5. } \\
\text { HIV block in macrophages } \\
\text { in vitro. }\end{array}$ & $\begin{array}{l}\text { Not conformed, human } \mathrm{Nt} \\
\text { sequences. } \\
\text { Low proportion of CCR5- } \\
\text { specific antibodies }\end{array}$ \\
\hline $\begin{array}{l}\text { Nt-and ECL2- } \\
\text { CCR5 }\end{array}$ & [94] & Preclinical, rats & $\begin{array}{l}\mathrm{Nt} \text {, cyclic ECL2 and } \\
\mathrm{Nt}+\text { cyclic ECL2 }\end{array}$ & $\begin{array}{l}\text { Phage Qbeta-based } \\
\text { VLPs by IM or } \\
\text { aerosol route }\end{array}$ & $\begin{array}{l}\text { Strong } \lg G \text { and } \lg A \text { in serum } \\
\text { Aerosol boost induced } \\
\text { mucosal IgA }\end{array}$ & $\begin{array}{l}\text { Macaque CCR5 } \\
\text { sequences. }\end{array}$ \\
\hline CCR5 Abs & [106] & Preclinical, mice & $\begin{array}{l}\text { Homologous, Nt, } \\
\text { ECL1, ECL2 } \\
\text { sequences conformed } \\
\text { in FHV capsid } \\
\text { protein. }\end{array}$ & $\begin{array}{l}\text { Alum best adjuvant } \\
\text { than Freund's, } \\
\text { RIBI, Montanide. } \\
\text { IM priming }+ \\
\text { mucosal IN } \\
\text { boosting best } \\
\text { schedule among } 13 \\
\text { protocols } \\
\text { compared. }\end{array}$ & $\begin{array}{l}\text { Murine CCR5 sequences. } \\
\text { Full tolerance break. } \\
\text { Serum and mucosal IgG and lgA. } \\
\text { Long lasting CCR5 downregulation in } \\
\text { PBMC } \\
\text { and mucosal fluids. } \\
\text { Mucosal IgA priming. } \\
\text { Transcytosis inhibition. No signs of } \\
\text { autoimmunity. }\end{array}$ & $\begin{array}{l}\text { Low IgA recovery from } \\
\text { mucosal fluids. }\end{array}$ \\
\hline
\end{tabular}

Table 3: Preclinical anti-CCR5 immunization studies in rodents. 
from CD4+ PBMCs, especially observed in cells isolated from vaginal fluids of mice vaccinated by mucosal route [87].

A recent preclinical study performed in mice have systematically addressed all aspects of anti-CCR5 immunization, including the use of adjuvants, in order to define the optimal schedule to elicit strong and long-lasting systemic and especially mucosal responses [106]. Three different immunogens, i.e. N-terminus, ECL1 and ECL2, expressed in the context of FHV capsid protein, were administered in 13 different protocols of immunization, comparing different combination of systemic and mucosal routes and four adjuvants (Table 3). Systemic IM priming and IN mucosal boosting with Aluminium adjuvant resulted the best combination and elicited high-titer specific antibodies. Not surprisingly, analysis of Peyer's patches revealed consistent priming in a high proportion of cells, showing an activated B phenotype and highlevels of IgA, representing up one-third of HIV-blocking antibodies.

ECL1 and ECL2 gave rise to stronger responses than N-terminus, achieving almost total CCR5 downregulation, sustained write block of HIV infection and nearly complete block of transcytosis. Most importantly, histopathological analysis found mild to moderate signs of chronic inflammation in some tissues, consistent with the activity of Aluminium adjuvant, but no signs of autoimmunity were observed [106].

\section{In vivo immunization\&challenge studies}

Results from immunization and challenge studies led to evaluate in vivo efficacy and safety, since CCR5 immune targeting raised concerns about the feasibility of a breakage in immune tolerance and the consequent risk of autoimmunity [107].

As summarized in Table 4, elicited anti-CCR5 antibodies were found to block HIV and SHIV infection in vitro, therefore showing that immune tolerance to a self antigen was broken; no immunized animal escaped infection, but reduced viral load and control of viremia in respect tounvaccinated control animals support the role of CCR 5 autoantibodies in controlling the infection [108-110].

Striking results come from a recent in vivo study, which confirms protective role of anti-CCR5 antibodies in vivo and suggests that this vaccination could really confer long-lasting in vivo protection (Table
4).A bacteriophage Qss VLP-based vaccine, presenting N-terminus and cyclic ECL2 peptides, was assayed in macaques before vaginal challenge with SIVmac251 [107]. Four vaccine doses were administered by intramuscular (IM) only or by intravaginal (IV) +IM routes.

After high-dose challenge, vaccinated animals showed 30-fold lower peaks and viremia than controls; in three out of twelve treated animals (25\%), one from IM and two from IM+IV groups, SIV nucleic acids become undetectable since six weeks p.i., not only in serum but also in lymph nodes and colon biopsies. Unfortunately, vaginal secretions could not be examined and so IgA levels were not evaluated. In vivo depletion of CD8+ T cells after one year p.i. failed to induce viral rebound, suggesting that protection did not depend on cytotoxic cells but mostly relied on humoral immunity; when anti-CCR 5 antibodies titer was vanished, i.e. more than one year after immunization, the three animals could become infected upon a new vaginal or intravenous high-dose challenge [111]. High-dose challenge was intended to clearly transmit infection in all controls and treated animals; however, highdose challenge is far from usual conditions of HIV transmission and could bring to underestimate the actual level of protection [103].

\section{Conclusions}

Responses from fresh studies confirm the important role of CCR5 molecule in HIV infection and maintenance, and get to consider its targeting is an attainable therapeutic goal. HIV story tells that many approaches and different therapeutic tools have been helpful to transform the acute infection in a chronic condition, with the aim at full virus eradication. On one hand, CCR5 and possibly CXCR4 gene ablation seem to promise the definitive eradication of HIV infection, albeit at heavy and costly conditions; similar efforts can be uniquely afforded by few chronic patients who cannot be longer treated with drugs or who need anticancer, life-saving interventions.

On the other hand, CCR5 immune targeting could offer effective and long-lasting preventive immunity, with low healthcare and individual burden. Both genetic and immune strategies offer specific rationale to fight HIV and find application in precise contexts; both of these could bring further development and offer new insight towards between the and control write HIV, although a CCR5 vaccine-based approach to induce CCR5 antibodies in groups at risk of contracting

\begin{tabular}{|c|c|c|c|c|c|c|}
\hline $\begin{array}{l}\text { Anti-CCR5 } \\
\text { Vaccine }\end{array}$ & Ref & Study & Immunogen/Vector & $\begin{array}{l}\text { Adjuvant//Route/ } \\
\text { Schedule }\end{array}$ & Biological features & Limits \\
\hline $\begin{array}{l}\text { CCR5 auto- } \\
\text { Abs }\end{array}$ & [108] & $\begin{array}{l}\text { Preclinical, } \\
\text { macaques } \\
\text { SHIV challenge }\end{array}$ & $\begin{array}{l}\text { High density Nt } \\
\text { peptides conjugated to } \\
\text { VLPs from BPV-L1 } \\
\text { protein. } \\
\text { Homologous, non } \\
\text { conformed macCCR5 } \\
\text { sequences were used. }\end{array}$ & $\begin{array}{l}9 \text { IM inocula with } \\
\text { TiterMax Gold } \\
\text { adjuvant }\end{array}$ & $\begin{array}{l}\text { Binding to native macCCR5 } \\
\text { in vitro SHIV block. } \\
\text { Reduced viral loads and time to } \\
\text { clearance upon IV infection with a } \\
\text { weakly pathogenic SHIV. } \\
\text { SHIV clearance correlated with anti- } \\
\text { CCR5 antibody titer and avidity. }\end{array}$ & $\begin{array}{l}\text { Abs titers were found to } \\
\text { decline over time but responded } \\
\text { to subsequent boosts. } \\
\text { No vaccinated macaque } \\
\text { escaped challenge, albeit } \\
\text { most of them controlled it. }\end{array}$ \\
\hline CCR5 Abs & [110] & $\begin{array}{l}\text { Preclinical, } \\
\text { macaques } \\
\text { SHIV challenge }\end{array}$ & $\begin{array}{l}\text { Cyclic ECL2 } \\
\text { (Arg168-Tyr177+CyscDDR5) } \\
\text { conjugated to } \\
\text { MAP poly-lysin resin }\end{array}$ & $\begin{array}{l}\text { Immunizations in } \\
\text { Complete (IP, 0, } \\
\text { 1wk) and } \\
\text { Incomplete (SC, } 6 \\
\text { wk) Freund's }\end{array}$ & $\begin{array}{l}\text { Binding to human and } \\
\text { macaque PBMCs. } \\
\text { In vitro block of laboratory } \\
\text { and primary isolates. } \\
\text { Reduction of viral load upon challenge. }\end{array}$ & $\begin{array}{l}\text { Infection was partly } \\
\text { controlled but not } \\
\text { prevented. }\end{array}$ \\
\hline CCR5 Abs & [111] & $\begin{array}{l}\text { Preclinical, } \\
\text { macaques } \\
\text { Vaginal SIV } \\
\text { challenges }\end{array}$ & $\begin{array}{l}\text { Nt and cyclic ECL2 } \\
\text { peptides in } \\
\text { bacteriophage Qss } \\
\text { VLPs } \\
\text { Homologous } \\
\text { macCCR5 sequences } \\
\text { were used. }\end{array}$ & $\begin{array}{l}4 \text { IM priming } \\
\text { (Freund's) } \\
+3 \text { vaginal } \\
\text { boosting }\end{array}$ & $\begin{array}{l}\text { Viremia peak } 30 \text {-fold lower } \\
\text { Undetectable SIV in } 3 / 12 \text { animals since } \\
6 \text { wk p.i. for more than a year in serum, } \\
\text { lymph nodes and colon biopsies. } \\
\text { Viral control due to humoral } \\
\text { but no to cell-mediated } \\
\text { immunity. }\end{array}$ & $\begin{array}{l}\text { Vaginal secretions could } \\
\text { not be examined. } \\
\text { IgA were not evaluated. } \\
\text { High dose challenges } \\
\text { could have even masked } \\
\text { the real extent of } \\
\text { protection }\end{array}$ \\
\hline
\end{tabular}

Table 4: Preclinical, anti-CCR5 immunization studies with virus challenges. 
HIV infection could be a more feasible and safe therapeutic goal than gene therapy, considering the HIV epidemiology and the difficulty of implementing CCR5 gene therapy in individuals residing in developing countries, of HIV infection.

\section{Acknowledgements}

The Authors wish to thank Silvia Russo, PhD, for her editorial help.

\section{References}

1. Cocchi F, DeVico AL, Garzino-Demo A, Arya SK, Gallo RC, et al. (1995) Identification of RANTES, MIP-1 alpha, and MIP-1 beta as the major HIVsuppressive factors produced by CD8+ T cells. Science 270: 1811-1815.

2. Huang Y, Paxton WA, Wolinsky SM, Neumann AU, Zhang L, et al. (1996) The role of a mutant CCR5 allele in HIV-1 transmission and disease progression. Nat Med 2: 1240-1243.

3. Liu R, Paxton WA, Choe S, Ceradini D, Martin SR, et al. (1996) Homozygous defect in HIV-1 coreceptor accounts for resistance of some multiply-exposed individuals to HIV-1 infection. Cell 86: 367-377.

4. Paxton WA, Liu R, Kang S, Wu L, Gingeras TR, et al. (1998) Reduced HIV1 infectability of CD4+ lymphocytes from exposed-uninfected individuals: association with low expression of CCR5 and high production of betachemokines. Virology 244: 66-73.

5. Paxton WA, Martin SR, Tse D, O'Brien TR, Skurnick J, et al. (1996) Relative resistance to HIV-1 infection of CD4 lymphocytes from persons who remain uninfected despite multiple high-risk sexual exposure. Nat Med 2: 412-417.

6. Samson M, Libert F, Doranz BJ, Rucker J, Liesnard C, et al. (1996) Resistance to HIV-1 infection in Caucasian individuals bearing mutant alleles of the CCR- 5 chemokine receptor gene. Nature 382: 722-725.

7. Ghorban K, Dadmanesh M, Hassanshahi G, Momeni M, Zare-Bidaki M, et al. (2013) Is the CCR5 Î" 32 mutation associated with immune system-related diseases? Inflammation 36: 633-642.

8. Muntinghe FL, Verduijn M, Zuurman MW, Grootendorst DC, Carrero JJ, et al. (2009) CCR5 deletion protects against inflammation-associated mortality in dialysis patients. J Am Soc Nephrol 20: 1641-1649.

9. Mahajan SD, Agosto-Mojica A, Aalinkeel R, Reynolds JL, Nair BB, et al. (2010) Role of chemokine and cytokine polymorphisms in the progression of HIV-1 disease. Biochem Biophys Res Commun 396: 348-352.

10. Mazzucchelli R, Corvasce S, Violin M, Riva C, Bianchi R, et al. (2001) Role of CCR5, CCR2 and SDF-1 gene polymorphisms in a population of HIV-1 infected individuals. J Biol Regul Homeost Agents 15: 265-271.

11. McDermott DH, Beecroft MJ, Kleeberger CA, Al-Sharif FM, Ollier WE, et al. (2000) Chemokine RANTES promoter polymorphism affects risk of both HIV infection and disease progression in the Multicenter AIDS Cohort Study. AIDS 14: $2671-2678$

12. Glass WG, McDermott DH, Lim JK, Lekhong S, Yu SF, et al. (2006) CCR5 deficiency increases risk of symptomatic West Nile virus infection. J Exp Med 203: 35-40.

13. Kindberg E, Mickiene A, Ax C, Akerlind B, Vene S, et al. (2008) A deletion in the chemokine receptor 5 (CCR5) gene is associated with tickborne encephalitis. $\mathrm{J}$ Infect Dis 197: 266-269.

14. Ma Q, Jones D, Borghesani PR, Segal RA, Nagasawa T, et al. (1998) Impaired B-lymphopoiesis, myelopoiesis, and derailed cerebellar neuron migration in CXCR4- and SDF-1-deficient mice. Proc Natl Acad Sci U S A 95: 9448-9453.

15. loannidis JP, Rosenberg PS, Goedert JJ, Ashton LJ, Benfield TL, et al. (2001) Effects of CCR5-Delta32, CCR2-64I, and SDF-1 3'A alleles on HIV-1 disease progression: An international meta-analysis of individual-patient data. Ann Intern Med 135: 782-795.

16. Su B, L Jin, F Hu, J Xiao, J Luo, et al. (1999) Distribution of two HIV 1 resistant polymorphisms (SDF1 3A and CCR2 64I) in East Asian and world populations and its implication in AIDS epidemiology. AmJHumGenet65: 10471053.

17. Bai X, Chen JD, Yang AG, Torti F, Chen SY (1998) Genetic co-inactivation of macrophage- and T-tropic HIV-1 chemokine coreceptors CCR-5 and CXCR-4 by intrakines. Gene Ther 5: 984-994.

18. Chung SH, Seki K, Choi BI, Kimura KB, Ito A, et al. (2010) CXC chemokine receptor 4 expressed in T cells plays an important role in the development of collagen-induced arthritis. Arthritis Res Ther 12: R188.

19. Hütter G, Nowak D, Mossner M, Ganepola S, Müssig A, et al. (2009) Long-term control of HIV by CCR5 Delta32/Delta32 stem-cell transplantation. N Engl J Med 360: 692-698.

20. Allers K, Hütter G, Hofmann J, Loddenkemper C, Rieger K, et al. (2011) Evidence for the cure of HIV infection by CCR $5 \Delta 32 / \Delta 32$ stem cell transplantation. Blood 117: 2791-2799.

21. Yukl SA, Boritz E, Busch M, Bentsen C, Chun TW, et al. (2013) Challenges in detecting HIV persistence during potentially curative interventions: a study of the Berlin patient. PLoS Pathog 9: e1003347.

22. Passaes CP, Sáez-Cirión A (2014) HIV cure research: advances and prospects Virology 454-455: 340-52.

23. Finzi D, Blankson J, Siliciano JD, Margolick JB, Chadwick K, et al. (1999) Latent infection of CD4+ T cells provides a mechanism for lifelong persistence of HIV 1 , even in patients on effective combination therapy. Nat Med 5: 512-517.

24. Lu Y, Nerurkar VR, Dashwood WM, Woodward CL, Ablan S, et al. (1999) Genotype and allele frequency of a 32 base pair deletion mutation in the CCR5 gene in various ethnic groups: absence of mutation among Asians and Pacific Islanders. Int J Infect Dis 3: 186-191.

25. Manjunath N, Yi G, Dang Y, Shankar P (2013) Newer gene editing technologies toward HIV gene therapy. Viruses 5: 2748-2766.

26. Jacobson JM (2013) HIV gene therapy research advances. Blood 121: 14831484.

27. Desmetz C, Lin YL, Mettling C, Portalès P, Noël D, et al. (2007) Cell surface CCR5 density determines the intensity of $\mathrm{T}$ cell migration towards rheumatoid arthritis synoviocytes. Clin Immunol 123: 148-154.

28. Murai M, Yoneyama H, Harada A, Yi Z, Vestergaard C, et al. (1999) Active participation of CCR5(+)CD8(+) T lymphocytes in the pathogenesis of liver injury in graft-versus-host disease. J Clin Invest 104: 49-57.

29. Tebas P, Stein D, Tang WW, Frank I, Wang SQ, et al. (2014) Gene editing of CCR5 in autologous CD4 T cells of persons infected with HIV. N Engl J Med 370: $901-910$.

30. Mussolino C, Morbitzer R, Lütge F, Dannemann N, Lahaye T, et al. (2011) A novel TALE nuclease scaffold enables high genome editing activity in combination with low toxicity. Nucleic Acids Res 39: 9283-9293.

31. Cho SW, Kim S, Kim JM, Kim JS (2013) Targeted genome engineering in human cells with the Cas9 RNA-guided endonuclease. Nat Biotechnol 31: 230232.

32. Cradick TJ, Fine EJ, Antico CJ, Bao G (2013) CRISPR/Cas9 systems targeting $\hat{I}^{2}$-globin and CCR5 genes have substantial off-target activity. Nucleic Acids Res 41: 9584-9592.

33. Perez EE, Wang J, Miller JC, Jouvenot Y, Kim KA, et al. (2008) Establishment of HIV-1 resistance in CD4+ T cells by genome editing using zinc-finger nucleases. Nat Biotechnol 26: 808-816.

34. Didigu CA, Wilen CB, Wang J, Duong J, Secreto AJ, et al. (2014) Simultaneous zinc-finger nuclease editing of the HIV coreceptors ccr5 and cxcr4 protects CD4+ T cells from HIV-1 infection. Blood 123: 61-69.

35. Bai J, Gorantla S, Banda N, Cagnon L, Rossi J, et al. (2000) Characterization of anti-CCR5 ribozyme-transduced CD34+ hematopoietic progenitor cells in vitro and in a SCID-hu mouse model in vivo. Mol Ther 1: 244-254.

36. Cordelier P, Morse B, Strayer DS (2003) Targeting CCR5 with siRNAs: using recombinant SV40-derived vectors to protect macrophages and microglia from R5-tropic HIV. Oligonucleotides 13: 281-294.

37. An DS, Donahue RE, Kamata M, Poon B, Metzger M, et al. (2007) Stable reduction of CCR5 by RNAi through hematopoietic stem cell transplant in nonhuman primates. Proc Natl Acad Sci U S A 104: 13110-13115.

38. An DS, Qin FX, Auyeung VC, Mao SH, Kung SK, et al. (2006) Optimization and functional effects of stable short hairpin RNA expression in primary human lymphocytes via lentiviral vectors. Mol Ther 14: 494-504.

39. Anderson JS, Walker J, Nolta JA, Bauer G (2009) Specific transduction of HIV-susceptible cells for CCR5 knockdown and resistance to HIV infection: a novel method for targeted gene therapy and intracellular immunization. J Acquir Immune Defic Syndr 52: 152-161. 
40. Tebas P, Stein D, Binder-Scholl G, Mukherjee R, Brady T, et al. (2013) Antiviral effects of autologous CD4 T cells genetically modified with a conditionally replicating lentiviral vector expressing long antisense to HIV. Blood 121: 15241533.

41. Levine BL, Humeau LM, Boyer J, MacGregor RR, Rebello T, et al. (2006) Gene transfer in humans using a conditionally replicating lentiviral vector. Proc Natl Acad Sci U S A 103: 17372-17377.

42. FishRJ, Kruithof EK (2004) Short term cytotoxic effects and long-term instability of RNAi delivered using lentiviral vectors . BMC Mol Biol 5: 9 .

43. Whitehead KA, JE Dahlman, RS Langer, and DG Anderson (2011) Silencing or stimulation? siRNA delivery and the immune system . Annu Rev Chem Biomol Eng 2: 77-96.

44. Rossi JJ, June CH, Kohn DB (2007) Genetic therapies against HIV. Nat Biotechnol 25: 1444-1454.

45. Qin XF, An DS, Chen IS, Baltimore D (2003) Inhibiting HIV-1 infection in human $T$ cells by lentiviral-mediated delivery of small interfering RNA against CCR5. Proc Natl Acad Sci U S A 100: 183-188.

46. Liang M, Kamata M, Chen KN, Pariente N, An DS, et al. (2010) Inhibition of HIV1 infection by a unique short hairpin RNA to chemokine receptor 5 delivered into macrophages through hematopoietic progenitor cell transduction. J Gene Med 12: 255-265.

47. Li M, Li H, Rossi JJ (2006) RNAi in combination with a ribozyme and TAR decoy for treatment of HIV infection in hematopoietic cell gene therapy. Ann N Y Acad Sci 1082: 172-179.

48. Cagnon L, Rossi JJ (2000) Downregulation of the CCR5 beta-chemokine receptor and inhibition of HIV-1 infection by stable VA1-ribozyme chimeric transcripts. Antisense Nucleic Acid Drug Dev 10: 251-261.

49. Nazari R, Ma XZ, Joshi S (2008) Inhibition of human immunodeficiency virus-1 entry using vectors expressing a multimeric hammerhead ribozyme targeting the CCR5 mRNA. J Gen Virol 89: 2252-2261.

50. Li MJ, Kim J, Li S, Zaia J, Yee JK, et al. (2005) Long-term inhibition of HIV1 infection in primary hematopoietic cells by lentiviral vector delivery of a triple combination of anti-HIV shRNA, anti-CCR5 ribozyme, and a nucleolarlocalizing TAR decoy. Mol Ther 12: 900-909.

51. von Recum HA1, Pokorski JK (2013) Peptide and protein-based inhibitors of HIV-1 co-receptors. Exp Biol Med (Maywood) 238: 442-449.

52. Chen JD, Bai X, Yang AG, Cong Y, Chen SY (1997) Inactivation of HIV-1 chemokine co-receptor CXCR-4 by a novel intrakine strategy. Nat Med 3: 11101116.

53. Yang AG, Bai X, Huang XF, Yao C, Chen S (1997) Phenotypic knockout of HIV type 1 chemokine coreceptor CCR- 5 by intrakines as potential therapeutic approach for HIV-1 infection. Proc Natl Acad Sci U S A 94: 11567-11572.

54. Schroers R, Davis CM, Wagner HJ, Chen SY (2002) Lentiviral transduction of human T-lymphocytes with a RANTES intrakine inhibits human immunodeficiency virus type 1 infection. Gene Ther 9: 889-897.

55. Salgado M, Simón A, Sanz-Minguela B, Rallón NI, López M, et al. (2011) An additive effect of protective host genetic factors correlates with HIV nonprogression status. J Acquir Immune Defic Syndr 56: 300-305.

56. Huik K, Sadam M, Karki T, Avi R, Krispin T, et al. (2010) CCL3L1 copy number is a strong genetic determinant of HIV seropositivity in Caucasian intravenous drug users. J Infect Dis 201: 730-739.

57. Aquaro S, Menten P, Struyf S, Proost P, Van Damme J, et al. (2001) The LD78beta isoform of MIP-1alpha is the most potent CC-chemokine in inhibiting CCR5-dependent human immunodeficiency virus type 1 replication in human macrophages. J Virol 75: 4402-4406.

58. Menten P, Struyf S, Schutyser E, Wuyts A, De Clercq E, et al. (1999) The LD78beta isoform of MIP-1alpha is the most potent CCR5 agonist and HIV-1inhibiting chemokine. J Clin Invest 104: R1-5.

59. Steinberger P, Andris-Widhopf J, Bühler B, Torbett BE, Barbas CF 3rd (2000) Functional deletion of the CCR5 receptor by intracellular immunization produces cells that are refractory to CCR5-dependent HIV-1 infection and cell fusion. Proc Natl Acad Sci U S A 97: 805-810.

60. Swan CH, Bühler B, Steinberger P, Tschan MP, Barbas CF 3rd, et al. (2006) T-cell protection and enrichment through lentiviral CCR5 intrabody gene delivery. Gene Ther 13: 1480-1492.
61. Aires da Silva F, Costa MJ, Corte-Real S, Goncalves J (2005) Cell type-specific targeting with sindbis pseudotyped lentiviral vectors displaying anti-CCR5 single-chain antibodies. Hum Gene Ther 16: 223-234.

62. Lopalco L (2004) Humoral immunity in HIV 1 exposure: cause or effect of HIV resistance? Curr HIV Res 2: 127-139.

63. Russo S, Lopalco L (2006) Is autoimmunity a component of natural immunity to HIV? Curr HIV Res 4: 177-190.

64. Blanpain C, Vanderwinden JM, Cihak J, Wittamer V, Le Poul E, et al. (2002) Multiple active states and oligomerization of CCR5 revealed by functional properties of monoclonal antibodies. Mol Biol Cell 13: 723-737.

65. Lee B, Sharron M, Blanpain C, Doranz BJ, Vakili J, et al. (1999) Epitope mapping of CCR5 reveals multiple conformational states and distinct but overlapping structures involved in chemokine and coreceptor function. J Biol Chem 274: 9617-9626.

66. Olson WC, Jacobson JM (2009) CCR5 monoclonal antibodies for HIV-1 therapy. Curr Opin HIV AIDS 4: 104-111.

67. Lopalco L (2 010) CCR5: From Natural Resistance to a New Anti-HIV Strategy Viruses 2: 574-600.

68. Jacobson JM, Lalezari JP, Thompson MA, Fichtenbaum CJ, Saag MS, et al (2010) Phase 2a study of the CCR5 monoclonal antibody PRO 140 administered intravenously to HIV-infected adults. Antimicrob Agents Chemother 54: 41374142 .

69. Jacobson JM, Saag MS, Thompson MA, Fischl MA, Liporace R, et al. (2008) Antiviral activity of single-dose PRO 140, a CCR5 monoclonal antibody, in HIVinfected adults. J Infect Dis 198: 1345-1352.

70. Jacobson JM, MA Thompson, JP Lalezari, MS Saag, BS Zingman, et al. (2010) Anti HIV 1 activity of weekly or biweekly treatment with subcutaneous PRO 140, a CCR5 monoclonal antibody . J Infect Dis 201: 1481-1487.

71. Lalezari J, Yadavalli GK, Para M, Richmond G, Dejesus E, et al. (2008) Safety, pharmacokinetics, and antiviral activity of $\mathrm{HGSO04}$, a novel fully human lgG4 monoclonal antibody against CCR5, in HIV-1-infected patients. J Infect Dis 197: 721-727.

72. Shimoni M, Herschhorn A, Britan-Rosich Y, Kotler M, Benhar I, et al. (2013) The isolation of novel phage display-derived human recombinant antibodies against CCR5, the major co-receptor of HIV. Viral Immunol 26: 277-290.

73. Steinberger P, Sutton JK, Rader C, Elia M, Barbas CF 3rd (2000) Generation and characterization of a recombinant human CCR5-specific antibody. A phage display approach for rabbit antibody humanization. J Biol Chem 275: 3607336078.

74. Zhang Y, Pool C, Sadler K, Yan HP, Edl J, et al. (2004) Selection of active ScFv to G-protein-coupled receptor CCR5 using surface antigen-mimicking peptides. Biochemistry 43: 12575-12584.

75. Pastori C, Weiser B, Barassi C, Uberti-Foppa C, Ghezzi S, et al. (2006) Long-lasting CCR5 internalization by antibodies in a subset of long-term nonprogressors: a possible protective effect against disease progression. Blood 107: 4825-4833.

76. Bouhlal H, Hocini H, Quillent-Grégoire C, Donkova V, Rose S, et al. (2001) Antibodies to $\mathrm{C}-\mathrm{C}$ chemokine receptor 5 in normal human IgG block infection of macrophages and lymphocytes with primary R5-tropic strains of HIV-1. J Immunol 166: 7606-7611.

77. Ditzel HJ, Rosenkilde MM, Garred P, Wang M, Koefoed K, et al. (1998) The CCR5 receptor acts as an alloantigen in CCR5Delta32 homozygous individuals: identification of chemokineand HIV-1-blocking human antibodies. Proc Natl Acad Sci U S A 95: 5241-5245.

78. Eslahpazir J, Jenabian MA, Bouhlal H, Hocini H, Carbonneil C, et al. (2008) Infection of macrophages and dendritic cells with primary R5-tropic human immunodeficiency virus type 1 inhibited by natural polyreactive anti-CCR5 antibodies purified from cervicovaginal secretions. Clin Vaccine Immunol 15: 872-884.

79. Grene E, Pinto LA, Kwak-Kim JY, Giorgi JV, Landay AL, et al. (2000) Increased levels of anti-CCR5 antibodies in sera from individuals immunized with allogeneic lymphocytes. AIDS 14: 2627-2628.

80. Barassi C, Marenzi C, Pastori C, Longhi R, Lazzarin A, et al. (2004) A new prospective against HIV infection: induction of murin CCR5-downregulating antibodies. New Microbiol 27: 85-94. 
81. Devito C, Broliden K, Kaul R, Svensson L, Johansen K, et al. (2000) Mucosal and plasma IgA from HIV-1-exposed uninfected individuals inhibit HIV-1 transcytosis across human epithelial cells. J Immunol 165: 5170-5176.

82. Devito C, Hinkula J, Kaul R, Lopalco L, Bwayo JJ, et al. (2000) Mucosal and plasma IgA from HIV-exposed seronegative individuals neutralize a primary HIV-1 isolate. AIDS 14: 1917-1920.

83. Lopalco L, Barassi C, Pastori C, Longhi R, Burastero SE, et al. (2000) CCR5reactive antibodies in seronegative partners of HIV-seropositive individuals down-modulate surface CCR5 in vivo and neutralize the infectivity of R5 strains of HIV-1 In vitro. J Immunol 164: 3426-3433.

84. Lopalco L, Barassi C, Paolucci C, Breda D, Brunelli D, et al. (2005) Predictive value of anti-cell and anti-human immunodeficiency virus (HIV) humoral responses in HIV-1-exposed seronegative cohorts of European and Asian origin. J Gen Virol 86: 339-348.

85. Bouhlal H, Latry V, Requena M, Aubry S, Kaveri SV, et al. (2005) Natural antibodies to CCR5 from breast milk block infection of macrophages and dendritic cells with primary R5-tropic HIV-1. J Immunol 174: 7202-7209.

86. Bomsel M, Pastori C, Tudor D, Alberti C, Garcia S, et al. (2007) Natural mucosal antibodies reactive with first extracellular loop of CCR5 inhibit HIV-1 transport across human epithelial cells. AIDS 21: 13-22.

87. Barassi C, Soprana E, Pastori C, Longhi R, Buratti E, et al. (2005) Induction of murine mucosal CCR5-reactive antibodies as an anti-human immunodeficiency virus strategy. J Virol 79: 6848-6858

88. Bogers WM, Bergmeier LA, Oostermeijer H, ten Haaft P, Wang Y, et al. (2004) CCR5 targeted SIV vaccination strategy preventing or inhibiting SIV infection. Vaccine 22: 2974-2984

89. Chain BM, Noursadeghi M, Gardener M, Tsang J, Wright E (2008) HIV blocking antibodies following immunisation with chimaeric peptides coding a short $\mathrm{N}$-terminal sequence of the CCR5 receptor. Vaccine 26: 5752-5759.

90. Misumi S, Endo M, Mukai R, Tachibana K, Umeda M, et al. (2003) A novel cyclic peptide immunization strategy for preventing HIV-1/AIDS infection and progression. J Biol Chem 278: 32335-32343.

91. Pastori C, Clivio A, Diomede L, Consonni R, De Mori GM, et al. (2008) Two amino acid substitutions within the first external loop of CCR5 induce human immunodeficiency virus-blocking antibodies in mice and chickens. J Virol 82: 4125-4134.

92. Klein JS, Bjorkman PJ (2010) Few and far between: how HIV may be evading antibody avidity. PLoS Pathog 6: e1000908.

93. Peabody DS, Manifold-Wheeler B, Medford A, Jordan SK, do Carmo Caldeira $\mathrm{J}$, et al. (2008) Immunogenic display of diverse peptides on virus-like particles of RNA phage MS2. J Mol Biol 380: 252-263.

94. Hunter Z, Smyth HD, Durfee P, Chackerian B (2009) Induction of mucosal and systemic antibody responses against the HIV coreceptor CCR5 upon intramuscular immunization and aerosol delivery of a virus-like particle based vaccine. Vaccine 28: 403-414.

95. Bomsel M, Alfsen A (2003) Entry of viruses through the epithelial barrier: pathogenic trickery. Nat Rev Mol Cell Biol 4: 57-68.

96. Ghosh M, Fahey JV, Shen Z, Lahey T, Cu-Uvin S, et al. (2010) Anti-HIV activity in cervical-vaginal secretions from HIV-positive and -negative women correlate with innate antimicrobial levels and IgG antibodies. PLoS One 5: e11366.

97. Rodriguez-Garcia M1, Patel MV, Wira CR (2013) Innate and adaptive anti-HIV immune responses in the female reproductive tract. J Reprod Immunol 97: 7484.
98. Agace WW, Amara A, Roberts Al, Pablos JL, Thelen S, et al. (2000) Constitutive expression of stromal derived factor- 1 by mucosal epithelia and its role in HIV transmission and propagation. Curr Biol 10: 325-328.

99. Bobardt MD, Chatterji U, Selvarajah S, Van der Schueren B, David G, et al. (2007) Cell free human immunodeficiency virus type 1 transcytosis through primary genital epithelial cells . J Virol 81: 395405.

100. Lawrence P, Portran D, Terrasse R, Palle S, Olivier T, et al. (2012) Selective transmigration of monocyte-associated HIV-1 across a human cervical monolayer and its modulation by seminal plasma. AIDS 26: 785-796.

101. Devito C, Zuber B, Schröder U, Benthin R, Okuda K, et al. (2004) Intranasal HIV-1-gp160-DNA/gp41 peptide prime-boost immunization regimen in mice results in long-term HIV-1 neutralizing humoral mucosal and systemic immunity. J Immunol 173: 7078-7089.

102. Tudor D, Derrien M, Diomede L, Drillet AS, Houimel M, et al. (2009) HIV-1 gp41-specific monoclonal mucosal IgAs derived from highly exposed but lgGseronegative individuals block HIV-1 epithelial transcytosis and neutralize CD4(+) cell infection: an IgA gene and functional analysis. Mucosal Immunol 2: $412-426$.

103. Bomsel M, Tudor D, Drillet AS, Alfsen A, Ganor Y, et al. (2011) Immunization with HIV-1 gp41 subunit virosomes induces mucosal antibodies protecting nonhuman primates against vaginal SHIV challenges. Immunity 34: 269-280.

104. Bonsignori M, Pollara J, Moody MA, Alpert MD, Chen X, et al. (2012) Antibodydependent cellular cytotoxicity-mediating antibodies from an HIV-1 vaccine efficacy trial target multiple epitopes and preferentially use the $\mathrm{VH} 1$ gene family. J Virol 86: 11521-11532.

105. Montefiori DC, Karnasuta C, Huang Y, Ahmed H, Gilbert P, et al. (2012) Magnitude and breadth of the neutralizing antibody response in the RV144 and Vax003 HIV-1 vaccine efficacy trials. J Infect Dis 206: 431-441.

106. Pastori C, Diomede L, Venuti A, Fisher G, Jarvik J, et al. (2014) Induction of HIV-blocking anti-CCR5 IgA in Peyers's patches without histopathological alterations. J Virol 88: 3623-3635.

107. Telenti A (2009) Safety concerns about CCR5 as an antiviral target. Curr Opin HIV AIDS 4: 131-135.

108. Chackerian B, Briglio L, Albert PS, Lowy DR, Schiller JT (2004) Induction of autoantibodies to CCR5 in macaques and subsequent effects upon challenge with an R5-tropic simian/human immunodeficiency virus. J Virol 78: 40374047.

109. Bogers WM, Bergmeier LA, Ma J, Oostermeijer H, Wang Y, et al. (2004) A novel HIV CCR5 receptor vaccine strategy in the control of mucosal SIV/HIV infection. AIDS 18: 25-36.

110. Misumi S, Nakayama D, Kusaba M, liboshi T, Mukai R, et al. (2006) Effects of immunization with CCR5-based cycloimmunogen on simian/HIVSF162P3 challenge. J Immunol 176: 463-471.

111. Van Rompay KK, Hunter Z, Jayashankar K, Peabody J, Montefiori D, et al. (2014) A vaccine against CCR5 protects a subset of macaques upon intravaginal challenge with simian immunodeficiency virus SIVmac251. J Virol 88: 2011-2024. 